\section{A genetic screen reveals Foxa3 and TNFR1 as key regulators of liver repopulation}

\author{
Kirk J. Wangensteen, ${ }^{1,2,3}$ Sophia Zhang, ${ }^{3}$ \\ Linda E. Greenbaum, ${ }^{4}$ and Klaus H. Kaestner ${ }^{1,2}$ \\ ${ }^{1}$ Department of Genetics, ${ }^{2}$ Center for Molecular Studies \\ in Digestive and Liver Diseases, University of Pennsylvania, \\ Philadelphia, Pennsylvania 19104, USA; ${ }^{3}$ Division of \\ Gastroenterology, Department of Medicine, University \\ of Pennsylvania, Philadelphia, Pennsylvania 19104, USA; \\ ${ }^{4}$ Janssen Research and Development, Spring House, \\ Pennsylvania 19477, USA
}

The fundamental question of which genes are most important in controlling liver regeneration remains unanswered. We employed a parallel screen to test the impact of 43 selected genes on liver repopulation in the $\mathrm{Fah}^{-/-}$mouse model of hereditary tyrosinemia. We discovered that the transcription factor Foxa3 was a strong promoter of liver regeneration, while tumor necrosis factor receptor 1 (TNFR1) was the most significant suppressor of repopulation among all of the genes tested. Our approach enabled the identification of these factors as important regulators of liver repopulation and potential drug targets for the promotion of liver repopulation.

Supplemental material is available for this article.

Received January 19, 2015; revised version accepted April 7, 2015.

A better understanding of how the liver regenerates in its attempts to recover from injuries, such as from exposure to drugs or alcohol or from infection by hepatitis viruses, could lead to new treatments with immense impact on the natural history of liver diseases. Previous efforts have relied on the easily accessible partial hepatectomy model in rodents (Fausto and Mead 1989; Fausto 1990, 2000, 2004; Fausto et al. 1995; Michalopoulos 2010), and many candidate genes were identified by expression profiling after partial hepatectomy (Kelley-Loughnane et al. 2002; Su et al. 2002; Fukuhara et al. 2003; White et al. 2005; Guo and Xu 2008; Cao et al. 2009; Li et al. 2009; Jiang et al. 2011; Schug et al. 2013). These results have implicated numerous pathways as being involved in regeneration, including growth factor pathways, kinases, transcription factors, and nuclear receptors, but did not inform us on the relative impact of the various genes on liver repopulation following toxic injury. Sequencing of multiple hepatocellular carcinomas (HCCs) identified a number of regulators of proliferation as well (Nishida and Kudo 2013; Tornesello et al. 2013). Despite an abundant number of genes that have been identified, no single gene, when mutated in animal models, seems to be

[Keywords: liver; regeneration; repopulation; injury; Foxa3; TNFR1] Corresponding author: kaestner@mail.med.upenn.edu

Article is online at http://www.genesdev.org/cgi/doi/10.1101/gad.258855. 115 . absolutely required for the recovery of liver mass following partial hepatectomy, suggesting that genetic redundancy may be an adaptation for such an important and conserved biological process as liver regeneration /Vogel 2006).

Genetic screens could be used to sort out the pathways that are key to the genetic control of liver regeneration. Recently, a shRNA screen of genes mutated in HCC was employed in a repopulation model to suggest the map kinase MKK4 as a regulator of liver repopulation (Wuestefeld et al. 2013). The experimental paradigm used was the $\mathrm{Fah}^{-1-}$ mouse model of liver repopulation, which has a defect in the last step of tyrosine catabolism, resulting in accumulation of the toxic metabolite fumarylacetoacetate (FAA) and injury to hepatocytes (Grompe 2001). Fah ${ }^{-1-}$ mice can be kept alive by treatment with 2-[2-nitro-4-(trifluoromethyl)benzoyl]cyclohexane1,3-dione (NTBC), a drug that inhibits an upstream enzyme in the tyrosine catabolic cascade to prevent formation of FAA. This model has been used to perform repopulation assays in the liver, where Fah-expressing hepatocytes divide and replace mutant hepatocytes after NTBC has been removed from the drinking water. We hypothesized that a competitive overexpression screen of genes implicated in controlling liver regeneration could identify factors that promote or inhibit liver repopulation in $\mathrm{Fah}^{-/-}$mice.

\section{Results and Discussion}

We constructed a library of plasmids in which the FAH transgene was linked to 43 potential positive and negative regulators as well as the reporter gene GFP as a neutral control (Fig. 1A; Supplemental Table S1). The genes were selected with an emphasis on transcription factors and potentially targetable protein products, such as cell surface and nuclear hormone receptors, cytokine receptors, and kinases. Genes were identified after a careful review of the literature on the genetic control of liver regeneration, major common insertion sites for genes identified in cancer genome sequencing projects, and role in liver stem cell biology and development. For genes in the latter category (namely, Foxa1, Foxa2, Foxa3, Foxl1, and Lgr5), little or no a priori data existed on their role in liver regeneration. Using the hydrodynamic injection technique (Liu et al. 1999; Zhang et al. 1999; Wilber et al. 2005; Wangensteen et al. 2008), the pool of 43 transgenes and GFP control constructs was stably introduced into a minority of hepatocytes in $\mathrm{Fah}^{-/-}$mice (estimated to be $\sim 0.1 \%$; Montini et al. 2002). Two days later, Fah-expressing hepatocytes were stimulated to undergo selective repopulation by removing the drug NTBC, which prevents toxin formation in Fah-deficient hepatocytes by inhibiting an upstream enzymatic step (Grompe 2001). Mouse livers were harvested at predetermined time points after removal of NTBC, DNA was extracted, and high-

(C) 2015 Wangensteen et al. This article is distributed exclusively by Cold Spring Harbor Laboratory Press for the first six months after the full-issue publication date (see http://genesdev.cshlp.org/site/misc/terms.xhtml). After six months, it is available under a Creative Commons License (Attribution-NonCommercial 4.0 International), as described at http:// creativecommons.org/licenses/by-nc/4.0/. 
A

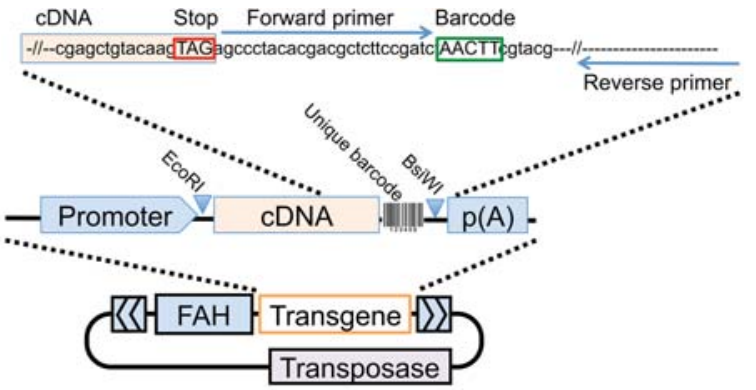

B
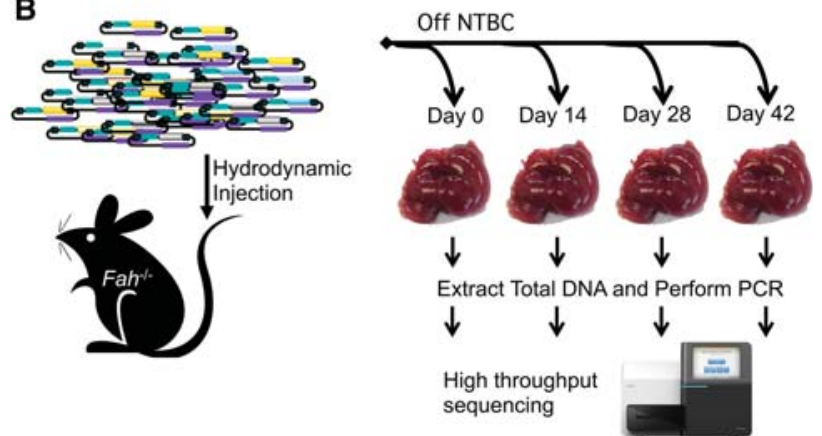

Figure 1. Schematic of the experimental design of the repopulation screen. (A) All 43 plasmids included in the screen (and the GFP control) employ the Sleeping Beauty transposon system to facilitate genomic integration of transposons containing wild-type Fah cDNA to correct the gene defect in $\mathrm{Fah}^{-1-}$ mouse hepatocytes as well as a transgene suspected of being involved in liver regeneration. Of note, each transposon construct contains a unique 5-nucleotide (nt) barcode corresponding to the linked transgene, flanked by primer binding sequences common to all constructs. $(B)$ High-throughput sequencing of the barcodes was used to measure the prevalence of each plasmid over time.

throughput sequencing was performed to determine the prevalence of each of the plasmids (Fig. 1B).

We verified that the constructs mediated repopulation of the livers of $\mathrm{Fah}^{-/-}$mice by performing immunohistochemistry (IHC) staining for Fah, which revealed expansion of Fah-positive hepatocyte nodules over the 6-wk time course (Fig. 2A). There was significant heterogeneity in nodule size, suggesting a differential effect on clonal outgrowth by the constructs. Whole DNA extracted from two large liver lobes at days $0,14,28$, and 42 after injection and removal of NTBC ( $N \geq 3$ for each time point) was amplified using primers common to all plasmids. The region amplified encompassed 5-nucleotide (nt) barcodes, which were high-throughput-sequenced. The read count was converted to prevalence for each plasmid over the time course (Fig. 2B; Supplemental Table S2). Several of the transgenes dramatically changed in prevalence compared with the GFP control plasmid over time. cMyc and TGFa were the greatest promoters of liver repopulation, consistent with their function as proto-oncogenes (Ohgaki et al. 1996; Kaposi-Novak et al. 2009). cMyc became the predominant transgene at $6 \mathrm{wk}$, going from a frequency of reads of $1.3 \%( \pm 0.02 \%)$ at the initial time point to $25 \%( \pm 0.53)$ at $6 \mathrm{wk}$, which skewed the frequency of the remaining genes downward over time. Next in prevalence after cMyc and TGFa, surprisingly, was Foxa3, a forkhead transcription factor that was not previously known to play any role in regeneration. Foxa3 increased in frequency of reads from $2.0 \%( \pm 0.05 \%)$ to $3.5 \%( \pm$
$0.7 \%$ ) over time, as compared with GFP, which went from $1.4 \%( \pm 0.03 \%)$ to $1.1 \%( \pm 0.2 \%)(P=0.033$ for comparison of Foxa3 to GFP at 6 wk after normalization to the mean value of the initial time point). Unexpectedly, the strongest suppressor of repopulation was tumor necrosis factor receptor 1 (TNFR1), the receptor for $\mathrm{TNFa}$, which decreased in frequency of reads from $1.1 \%$ $0.09 \%)$ to $0.098 \%( \pm 0.02 \%)(P=0.004$ compared with GFP at $6 \mathrm{wk}$, after normalization to the mean value of the initial time point) (Byl et al. 1993).

Foxa1, Foxa2, and Foxa3 are homologous forkhead transcription factors essential for liver development and are termed "pioneer factors" for their ability to access areas of heterochromatin to activate gene transcription (Zaret 1999; Le Lay and Kaestner 2010). Foxa3 is the most highly expressed of the Foxa factors in the adult liver and is dispensable for liver development (Kaestner et al. 1994). Foxa3 is one of three to four factors that are sufficient to convert fibroblasts into hepatocyte-like cells (Huang et al. 2011; Sekiya and Suzuki 2011). We confirmed that Foxa3 overexpression indeed promotes liver regeneration by using a competitive repopulation assay (Fig. 3A). We injected FAH-Foxa3 and FAH-GFP plasmids in equimolar amounts into $\mathrm{Fah}^{-1-}$ mice $(N=3)$ and removed NTBC to stimulate repopulation. Four weeks after injection, we performed Foxa3 and GFP immunofluorescence and determined that the size and number of Foxa3-expressing repopulation nodules were greater than those of GFPexpressing nodules (Fig. 3B,C). We performed quantitative PCR (qPCR) on extracted DNA to quantify the abundance of the two transgenes and found that FAH-Foxa3 was enriched compared with FAH-GFP after repopulation, confirming that Foxa3 indeed promotes liver repopulation (Fig. 3D).

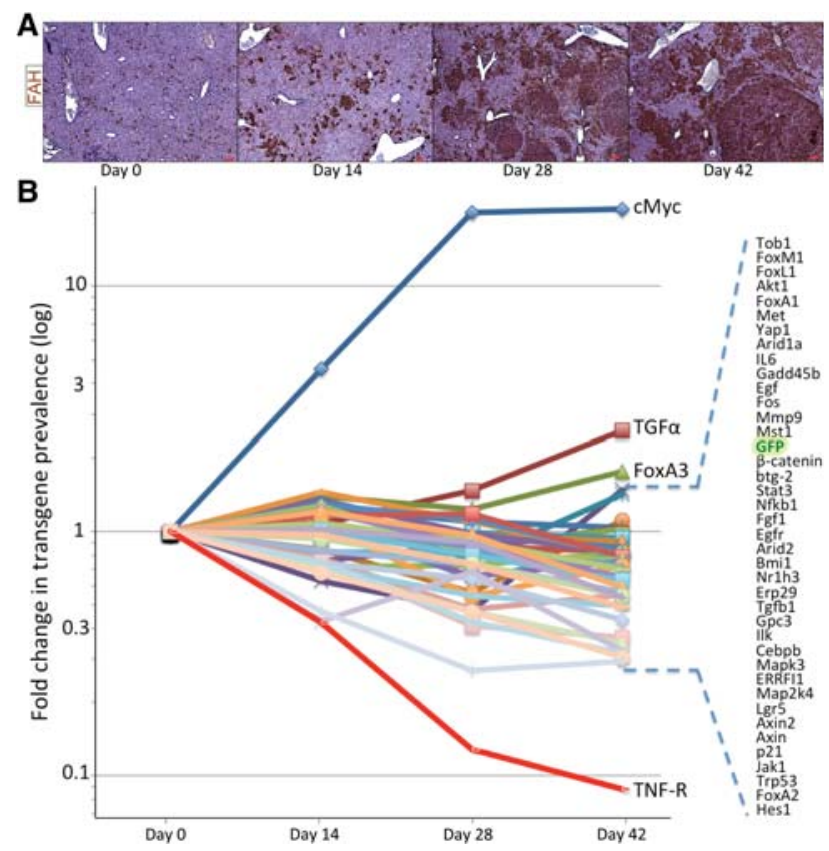

Figure 2. Competitive in vivo screen identifies promoters and inhibitors of liver repopulation. (A) IHC staining for FAH showing increasing nodule size over time. Bar, $100 \mu \mathrm{m}$. (B) Graph showing the proportion of each plasmid over the 6-wk repopulation time course relative to day $0 . N=3$ for day 0 , day 14 , and day $42 ; N=4$ for day 28 . 

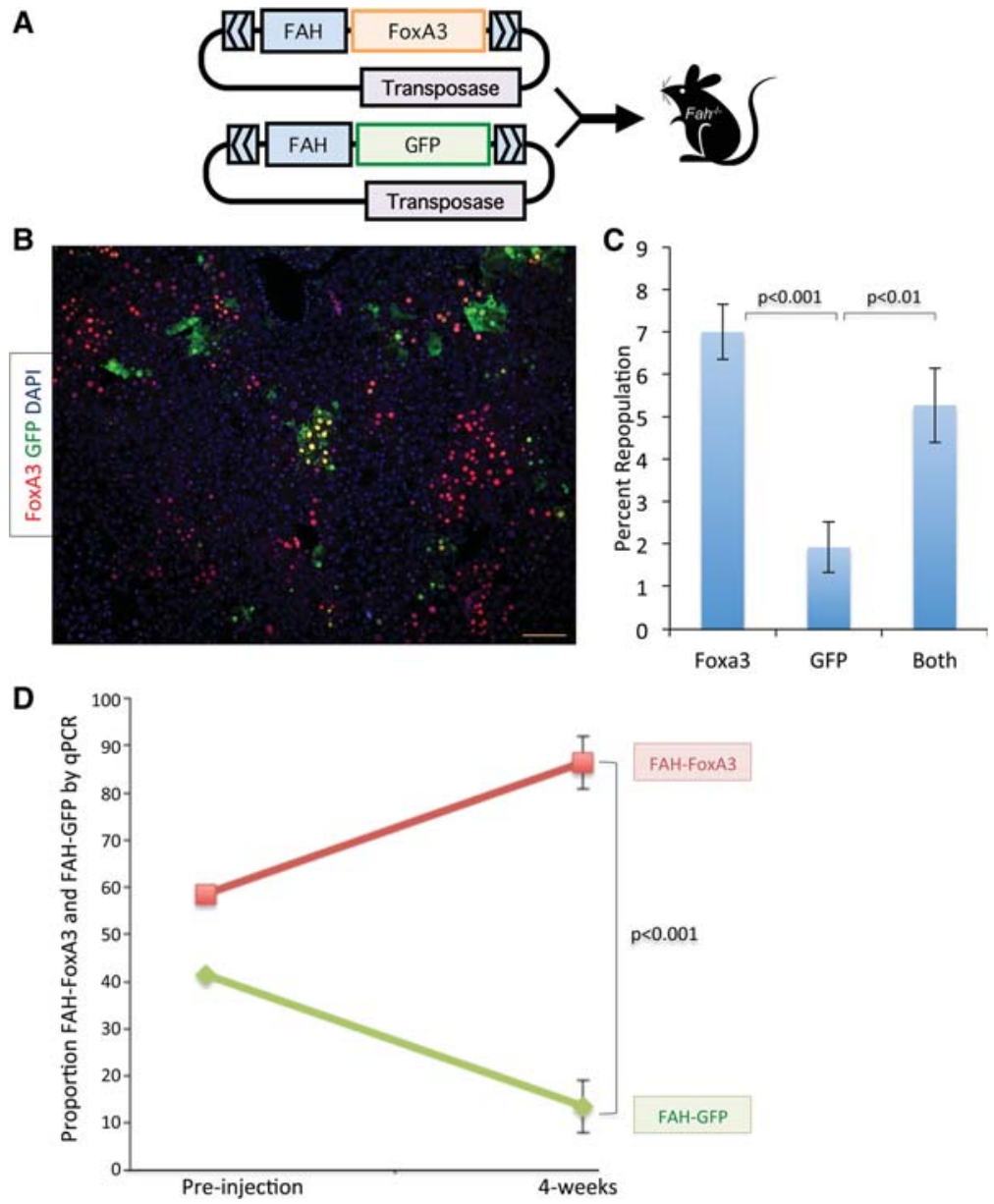

Figure 3. Foxa3 is a robust promoter of liver repopulation. (A) Schematic of the competitive assay to compare FAH-Foxa3 and FAH-GFP plasmids. FAH-Foxa3 and FAHGFP were injected in equimolar amounts into three $\mathrm{Fah}^{-1-}$ mice, NTBC treatment was discontinued, and the mice were maintained for $28 \mathrm{~d}$ to enable liver repopulation with the transfected hepatocytes. Mice were then euthanized, and liver tissue was removed for histology and qPCR. $(B)$ Immunofluorescence staining showing nodules of GFP (green), FoxA3 (red), or both (yellow). Bar, $100 \mu \mathrm{m}$. (C) Quantification of the percentage of repopulation by Foxa3 versus GFP versus double positive. $N=3$ biological replicates. SE bars are shown. (D) qPCR of plasmids at 4 wk after injection. $N=3$ biological replicates. SE bars are shown.

TNFR1 is part of a family of cell surface proteins (commonly known as the death receptors) that are expressed at high levels in hepatocytes, possibly to trigger eradication of hepatocytes that become infected with viruses (Akazawa and Gores 2007). The ligand for TNFR1 is TNFa, a cytokine that becomes elevated in cirrhosis and alcoholic liver disease (Byl et al. 1993). TNFa in rodents has been found to have a dichotomous role as a mitogen during liver regeneration after partial hepatectomy and as an activator of apoptosis in the setting of exposure to toxins such as alcohol (Bradham et al. 1998). The molecular context of TNFR1 activation is thought to dictate whether it supports the regenerative response or causes hepatocyte death (Luedde et al. 2014). To verify whether TNFR1 expression inhibits liver repopulation, we injected either FAH-TNFR1 or an equimolar amount of FAH-GFP plasmid into separate $\mathrm{Fah}^{-1-}$ mice (Fig. 4A). We found that, as compared with mice injected with the FAH-GFP plasmids, mice injected with FAH-TNFR1 lost significantly more weight and exhibited increased mortality after removal of NTBC (Fig. 4B). At 4 wk after injection, surviving mice from each group were euthanized. Analysis of serum chemistries indicated decreased albumin and markedly elevated total bilirubin, AST, and ALT with FAH-TNFR1 as compared with FAH-GFP, indicating that TNFR1 expression in repopulating liver cells leads to severe liver injury in $\mathrm{Fah}^{-9}$ mice ( $N=3$ each) (Fig. 4C). Immunohistochemical staining for FAH indicated significantly greater repopulation with FAH-GFP than with FAH-TNFR1 ( $N=3$ each) (Fig. 4D). With FAH-TNFR1, the Fah-positive cells were dysmorphic and had heterogenous Fah staining intensity. We compared proliferation in the two groups by staining with the cell cycle marker Ki67 and found many more cells to be proliferating in FAH-GFP-treated livers than in FAH-TNFR1 1 mo after injection (Fig. 4E). In contrast, p21, a marker of cell cycle arrest, was strongly induced in repopulating FAHTNFR1-positive cells and was absent in FAHGFP-repopulating hepatocytes (Fig. 4E). Interestingly, TUNEL assay for apoptosis revealed only a few scattered TUNEL-positive cells in both groups (data not shown), consistent with previous reports that injured hepatocytes in $\mathrm{Fah}^{-/-}$mice undergo apoptosis arrest (Willenbring et al. 2008). In summary, expression of TNFR1 in repopulating hepatocytes leads to a proliferation arrest with toxicity from inappropriate activation of the TNFR1 pathway and constitutive expression of the cell cycle inhibitor p21.

In conclusion, we used a competitive in vivo screening paradigm to discover Foxa3 and TNFR1 as critical modulators of liver repopulation. Previous efforts had identified pathways as being involved in liver regeneration following partial hepatectomy but had never compared multiple genes in a clinically relevant liver injury model. Our method enabled the direct comparison of overexpressed genes in repopulating liver cells. Foxa3 is a transcription factor that likely establishes a transcriptional program to potently enhance liver repopulation. TNFR1, in contrast, strongly inhibits liver repopulation, possibly by sensitizing hepatocytes to TNF signaling in the context of liver injury. Interestingly, we found that expression levels of both TNFR1 and its ligand, TNFa, increase twofold in the liver after partial hepatectomy in our previously published gene expression data set (Schug et al. 2013). The disparate findings with TNF signaling in promotion of regeneration after partial hepatectomy as opposed to inhibition of repopulation in the $\mathrm{Fah}^{-/-}$model may be due to a sensitivity to level of activation of TNF signaling, the duration of injury, or the inflammatory context in toxic liver injury. Interestingly, a recent study demonstrated that blockade of TNF signaling with etanercept promoted engraftment of transplanted hepatocytes in a rat model (Viswanathan et al. 2014). Taken together, these data suggest that inhibition of TNFR1 expression or activity in hepatocytes may represent a novel strategy to promote healthy repopulation in the context of toxic liver injury. 
A

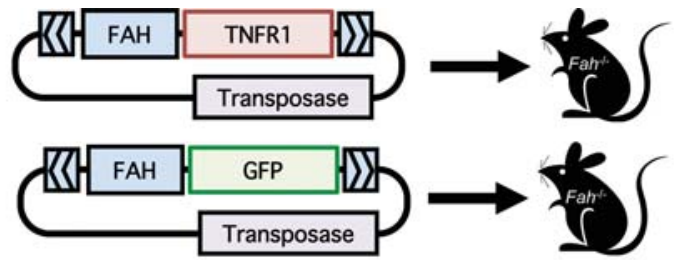

B

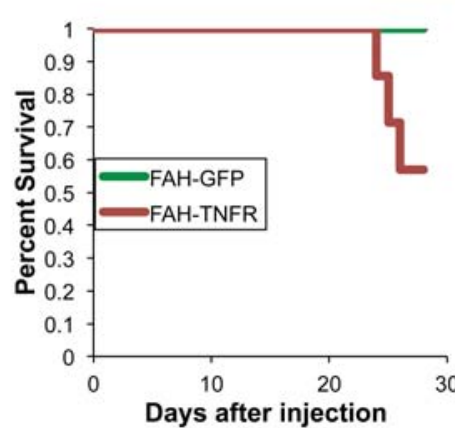

\begin{tabular}{|l|l|l|l|}
\hline \multicolumn{1}{|l|}{} & FAH-GFP & FAH-TNFR & P value \\
\hline Albumin (2.6-3.8) & $2.1 \pm 0.1$ & $1.3 \pm .1$ & 0.01 \\
\hline Total Bilirubin (0.1-0.9) & $0.6 \pm 0.2$ & $11.0 \pm 1.2$ & 0.001 \\
\hline AST (59-247) & $308 \pm 70$ & $868 \pm 7$ & 0.01 \\
\hline ALT (28-132) & $103 \pm 18$ & $500 \pm 102$ & 0.02 \\
\hline Creatinine (0-0.8) & $0.1 \pm 0.03$ & $0 \pm 0$ & 0.1 \\
\hline Ammonia (46-172) & $473 \pm 117$ & $535 \pm 97$ & 0.7 \\
\hline
\end{tabular}

D FAH-GFP

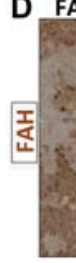

FAH-TNFR1

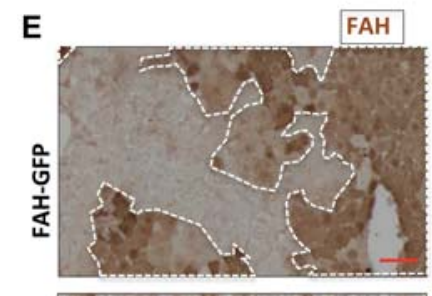

E

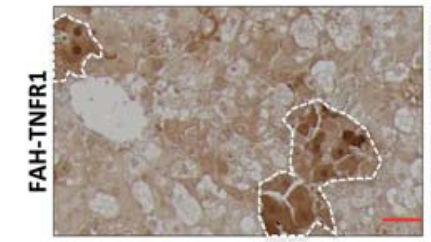

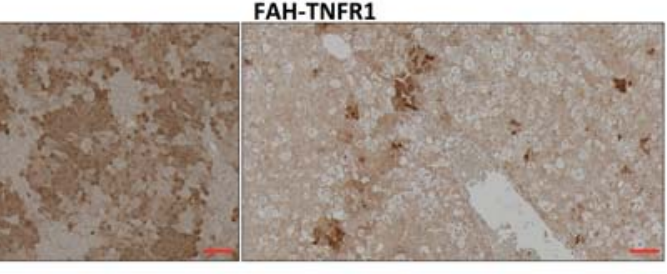

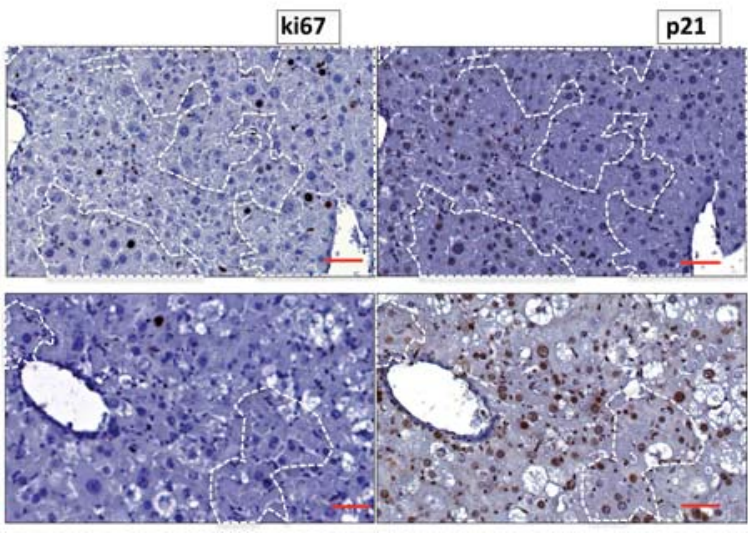

Figure 4. Liver repopulation is severely impaired by elevated TNFR1 expression in hepatocytes. $(A)$ Schematic of the experimental design comparing FAH-TNFR1 and FAH-GFP plasmids. Either FAH-TNFR1 or FAH-GFP was injected into Fah ${ }^{-/-}$mice, followed by removal of NTBC and repopulation over the course of $28 \mathrm{~d}$. Mice were then euthanized, serum was extracted, and liver tissue was removed for histology. $(B)$ KaplanMeier survival plot showing that all FAH-GFP-treated mice survived $(N=6)$, whereas only four out of seven mice treated with FAH-TNFR1 survived to $28 \mathrm{~d}$. (C) Serum chemistry values at $28 \mathrm{~d}$ of repopulation \pm SE values. $N=3$ biological replicates. $(D, 1 e f t)$ IHC staining for FAH. Bar, 100 $\mu \mathrm{m}$. (Right) Quantification of repopulation area. $N=3$ biological replicates each. SE bars are shown. $(E)$ Serial sections with IHC for FAH, ki67, and p21. Bar, $50 \mu \mathrm{m}$.

\section{Materials and methods}

\section{Plasmid construction and sequencing}

Plasmid pKT2/FAH-CA//SB (Wangensteen et al. 2008) was used as the base plasmid to clone cDNAs downstream from a miniCagg promoter. cDNA for GFP was initially cloned at the EcoRI site, with BsiWI sequence added to the $3^{\prime}$ end to facilitate directional cloning. Mouse full-length cDNAs were PCR-amplified from plasmids obtained from repositories (PlasmID DNA Resource Core [Harvard University, Cambridge, MA] and Addgene) or mouse liver cDNA libraries. Primers used to amplify the cDNA all included 5' primers with an EcoRI restriction site and $3^{\prime}$ primers with a BsiWI site, the Illumina $5^{\prime}$-ILMN sequencing primer sequence $\left(5^{\prime}\right.$-CCCTACAC-
GACGCTCTTCCGATCT-3'), and a unique 5-nt barcode sequence (Supplemental Table S1). The unique barcode sequences were generated using Barcode Generator free software (http://comailab.genomecenter. ucdavis.edu/index.php/Barcode_generator). Plasmids were all endotoxinfree maxi-prepped (Sigma), and Sanger sequencing was used to verify correct full-length sequences for all cDNAs. The library pool was generated by combining equimolar amounts of each plasmid.

For quantitative sequencing of the plasmid barcodes, whole DNA was extracted from a homogenate of two large liver lobes from mice euthanized at days $0,14,28$, and 42 after injection (Qiagen). Two rounds of PCR were performed to amplify the sequences containing the unique barcodes using primers L-adapter (5'-CCTACACGACGCTCTTCCGATCT- $\left.3^{\prime}\right)$ and Radapter-1 (5'-AGACGTGTGCTCTTCCGATCTCAGGGCATTGGCCA 
CACCAG-3'| for the first round, followed by DNA purification and a second PCR round with universal adapter primer $\left(5^{\prime}\right.$-AATGATACGGCGA CCACCGAGATCTACCACTCTTTCCCTACACGACGCTCTTCCGAT CT- $3^{\prime}$ ) and a $3^{\prime}$ multiplexing primer (Illumina TruSeq). The DNA was purified, and qPCR was performed to accurately quantify the amount of product (Kapa Biosystems). An Illumina MiSeq sequencer was used to sequence the unique 5-nt barcodes using the $5^{\prime}$-ILMN primer, and a $3^{\prime}$ primer was used to sequence linked 6-nt multiplex "index" sequences. The barcode and index sequences were demultiplexed to generate a table with a read count for each barcode for each animal, and these were divided by the total number of reads for each animal to generate the prevalence quotient for each plasmid. The plasmid prevalences were averaged for each time point ( $N=3$ for day zero, day 14 , and day $42 ; N=4$ for day 28) (Supplemental Table S2) and then normalized to day 0 values to generate the graph in Figure 2B. Microsoft Excel was used for analysis of the data, graphing, calculation of standard deviation and standard error, and Student's $t$-test of biological replicates.

\section{Mouse experiments}

$\mathrm{Fah}^{-1-}$ mice were provided by Markus Grompe and were maintained on $7.5 \mu \mathrm{g} / \mathrm{mL}$ NTBC until injection with the FAH transposon plasmids. Mice between 6 and 8 wk of age were injected with $10 \mu \mathrm{g}$ of DNA by the hydrodynamic technique as described (Wangensteen et al. 2008). Mouse weight and mortality were monitored until mice were euthanized at 2, 4 or 6 wk after injection. At the time of euthanasia, serum was extracted from the inferior vena cava, and separate liver lobes were harvested and either flash-frozen with dry ice or fixed with $4 \%$ paraformaldehyde. Serum biochemistries were determined by the University of Pennsylvania Mouse Phenotyping, Physiology, and Metabolism Core. Student's $t$-test was used to calculate statistical differences of biological replicates.

\section{qPCR}

Genomic DNA was separately extracted from whole liver lobes of three mice $1 \mathrm{mo}$ after injection of an equimolar mix of FAH-GFP and FAHFoxa3 (DNeasy, Qiagen). qPCR was performed using PrimeTime primer sets (IDT DNA): a common primer set (FWD, 5'-CCTACACGCGCTCTT CC-3'; REV, 5'-TCAGTGGTATTTGTGAGCCA-3'; and probe, /56-FAM/ AAATTCACT/Zen/CCTCAGGTGCAGGCT/3IABkFQ//, a GFP- specific set (FWD, 5'-GAACCGCATCGAGCTGAA-3'; REV, 5'-TGCTTGTCGG CCATGATATAG-3' ${ }^{\prime}$ and probe, /5HEX/ATCGACTTC/ZEN/AAGGAGG ACGGCAAC/3IABkFQ//, and a Foxa3-specific set (FWD, 5'-CTCCTTCG TCCACACCTTATTT-3'; REV, 5'-AAGGTGTCGATGTCTGTTCTG-3'; and probe, /5Cy5/AGGGTGGTTGAAGTTATAGGGCGC/3IABkFQ//. The prevalence of FAH-GFP and FAH-Foxa3 plasmids was calculated as a proportion of the total number of plasmids. Student's $t$-test was used to calculate the statistical differences between the biological replicates.

\section{Histology}

Fixed liver tissues were paraffinized and sectioned. IHC staining was performed using standard techniques with rabbit anti-FAH antibody (Abcam), anti-ki67, or anti-p21 followed by corresponding secondary antibodies. Immunofluorescence was performed using standard techniques with goat anti-GFP and rabbit anti-FoxA3. ImageJ was used for morphometric analysis, and Student's $t$-test was used to calculate statistical differences of biological replicates.

\section{Acknowledgments}

We thank Elham Mosleh for technical support, and Ann M. Tierney for helpful discussions about statistics. This study was supported by National Institutes of Health grants P01DK049210 to K.H.K, and T32DK007066 to K.J.W. Core support was provided by the University of Pennsylvania Morphology Core (P30-DK50306) and Functional Genomics Core.

\section{References}

Akazawa Y, Gores GJ. 2007. Death receptor-mediated liver injury. Semin Liver Dis 27: 327-338.
Bradham CA, Plumpe I, Manns MP, Brenner DA, Trautwein C. 1998 Mechanisms of hepatic toxicity. I. TNF-induced liver injury. Am J Physiol 275: G387-G392.

Byl B, Roucloux I, Crusiaux A, Dupont E, Deviere J. 1993. Tumor necrosis factor $\alpha$ and interleukin 6 plasma levels in infected cirrhotic patients. Gastroenterology 104: 1492-1497.

Cao H, Yu J, Xu W, Jia X, Yang J, Pan Q, Zhang Q, Sheng G, Li J, Pan X, et al. 2009. Proteomic analysis of regenerating mouse liver following $50 \%$ partial hepatectomy. Proteome Sci 7: 48.

Fausto N. 1990. Hepatocyte differentiation and liver progenitor cells. Curr Opin Cell Biol 2: 1036-1042.

Fausto N. 2000. Liver regeneration. J Hepatol 32: 19-31.

Fausto N. 2004. Liver regeneration and repair: hepatocytes, progenitor cells, and stem cells. Hepatology 39: 1477-1487.

Fausto N, Mead JE. 1989. Regulation of liver growth: protooncogenes and transforming growth factors. Lab Invest 60: 4-13.

Fausto N, Laird AD, Webber EM. 1995. Role of growth factors and cytokines in hepatic regeneration. FASEB I 9: 1527-1536.

Fukuhara Y, Hirasawa A, Li XK, Kawasaki M, Fujino M, Funeshima N, Katsuma S, Shiojima S, Yamada M, Okuyama T, et al. 2003. Gene expression profile in the regenerating rat liver after partial hepatectomy. J Hepatol 38: 784-792.

Grompe M. 2001. The pathophysiology and treatment of hereditary tyrosinemia type 1. Semin Liver Dis 21: 563-571.

Guo GB, Xu CS. 2008. Expression profiles of the organic acid metabolismassociated genes during rat liver regeneration. Amino Acids 34: 597604.

Huang P, He Z, Ji S, Sun H, Xiang D, Liu C, Hu Y, Wang X, Hui L. 2011. Induction of functional hepatocyte-like cells from mouse fibroblasts by defined factors. Nature 475: 386-389.

Jiang Y, Zhang LX, Chang CF, Wang GP, Shi RJ, Yang YJ, Xu CS. 2011. The number of the genes in a functional category matters during rat liver regeneration after partial hepatectomy. I Cell Biochem 112: 3194-3205.

Kaestner KH, Hiemisch H, Luckow B, Schutz G. 1994. The HNF-3 gene family of transcription factors in mice: gene structure, cDNA sequence, and mRNA distribution. Genomics 20: 377-385.

Kaposi-Novak P, Libbrecht L, Woo HG, Lee YH, Sears NC, Coulouarn C, Conner EA, Factor VM, Roskams T, Thorgeirsson SS. 2009. Central role of c-Myc during malignant conversion in human hepatocarcinogenesis. Cancer Res 69: 2775-2782.

Kelley-Loughnane N, Sabla GE, Ley-Ebert C, Aronow BJ, Bezerra JA. 2002. Independent and overlapping transcriptional activation during liver development and regeneration in mice. Hepatology 35: 525-534.

Le Lay J, Kaestner KH. 2010. The Fox genes in the liver: from organogenesis to functional integration. Physiol Rev 90: 1-22.

Li J, Campbell JS, Mitchell C, McMahan RS, Yu X, Riehle KJ, Bumgarner RE, Fausto N. 2009. Relationships between deficits in tissue mass and transcriptional programs after partial hepatectomy in mice. Am J Pathol 175: 947-957.

Liu Y, Thor A, Shtivelman E, Cao Y, Tu G, Heath TD, Debs RJ. 1999. Systemic gene delivery expands the repertoire of effective antiangiogenic agents. I Biol Chem 274: 13338-13344.

Luedde T, Kaplowitz N, Schwabe RF. 2014. Cell death and cell death responses in liver disease: mechanisms and clinical relevance. Gastroenterology 147: 765-783 e764.

Michalopoulos GK. 2010. Liver regeneration after partial hepatectomy: critical analysis of mechanistic dilemmas. Am J Pathol 176: 2-13.

Montini E, Held PK, Noll M, Morcinek N, Al-Dhalimy M, Finegold M, Yant SR, Kay MA, Grompe M. 2002. In vivo correction of murine tyrosinemia type I by DNA-mediated transposition. Mol Ther 6: 759-769.

Nishida N, Kudo M. 2013. Recent advancements in comprehensive genetic analyses for human hepatocellular carcinoma. Oncology 84: 93-97.

Ohgaki H, Sanderson ND, Ton P, Thorgeirsson SS. 1996. Molecular analyses of liver tumors in c-myc transgenic mice and c-myc and TGF- $\alpha$ double transgenic mice. Cancer Lett 106: 43-49.

Schug J, McKenna LB, Walton G, Hand N, Mukherjee S, Essuman K, Shi Z, Gao Y, Markley K, Nakagawa M, et al. 2013. Dynamic recruitment of 
microRNAs to their mRNA targets in the regenerating liver. BMC Genomics 14: 264 .

Sekiya S, Suzuki A. 2011. Direct conversion of mouse fibroblasts to hepatocyte-like cells by defined factors. Nature 475: 390-393.

Su AI, Guidotti LG, Pezacki JP, Chisari FV, Schultz PG. 2002. Gene expression during the priming phase of liver regeneration after partial hepatectomy in mice. Proc Natl Acad Sci 99: 11181-11186.

Tornesello ML, Buonaguro L, Tatangelo F, Botti G, Izzo F, Buonaguro FM. 2013. Mutations in TP53, CTNNB1 and PIK3CA genes in hepatocellular carcinoma associated with hepatitis B and hepatitis $C$ virus infections. Genomics 102: 74-83.

Viswanathan P, Kapoor S, Kumaran V, Joseph B, Gupta S. 2014. Etanercept blocks inflammatory responses orchestrated by TNF- $a$ to promote transplanted cell engraftment and proliferation in rat liver. Hepatology 60: $1378-1388$.

Vogel G. 2006. Development. Two unexpected players add twists to liver's comeback story. Science 312: 178 .

Wangensteen KJ, Wilber A, Keng VW, He Z, Matise I, Wangensteen L, Carson CM, Chen Y, Steer CJ, McIvor RS, et al. 2008. A facile method for somatic, lifelong manipulation of multiple genes in the mouse liver. Hepatology 47: 1714-1724.
White P, Brestelli JE, Kaestner KH, Greenbaum LE. 2005. Identification of transcriptional networks during liver regeneration. J Biol Chem 280: 3715-3722.

Wilber A, Frandsen JL, Wangensteen KJ, Ekker SC, Wang X, McIvor RS. 2005. Dynamic gene expression after systemic delivery of plasmid DNA as determined by in vivo bioluminescence imaging. Hum Gene Ther 16: 1325-1332.

Willenbring H, Sharma AD, Vogel A, Lee AY, Rothfuss A, Wang Z, Finegold M, Grompe M. 2008. Loss of p21 permits carcinogenesis from chronically damaged liver and kidney epithelial cells despite unchecked apoptosis. Cancer Cell 14: 59-67.

Wuestefeld T, Pesic M, Rudalska R, Dauch D, Longerich T, Kang TW, Yevsa T, Heinzmann F, Hoenicke L, Hohmeyer A, et al. 2013. A Direct in vivo RNAi screen identifies MKK4 as a key regulator of liver regeneration. Cell 153: 389-401.

Zaret K. 1999. Developmental competence of the gut endoderm: genetic potentiation by GATA and HNF3/fork head proteins. Dev Biol 209: $1-10$

Zhang G, Budker V, Wolff JA. 1999. High levels of foreign gene expression in hepatocytes after tail vein injections of naked plasmid DNA. Hum Gene Ther 10: 1735-1737. 


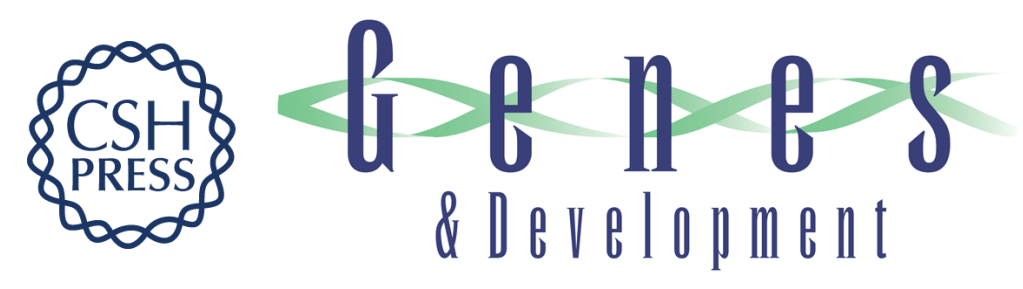

\section{A genetic screen reveals Foxa3 and TNFR1 as key regulators of liver repopulation}

Kirk J. Wangensteen, Sophia Zhang, Linda E. Greenbaum, et al.

Genes Dev. 2015, 29:

Access the most recent version at doi:10.1101/gad.258855.115

\section{Supplemental http://genesdev.cshlp.org/content/suppl/2015/04/30/29.9.904.DC1 Material}

References This article cites 38 articles, 4 of which can be accessed free at: http://genesdev.cshlp.org/content/29/9/904.full.html\#ref-list-1

Creative This article is distributed exclusively by Cold Spring Harbor Laboratory Press for the first Commons six months after the full-issue publication date (see

License http://genesdev.cshlp.org/site/misc/terms.xhtml). After six months, it is available under a Creative Commons License (Attribution-NonCommercial 4.0 International), as described at http://creativecommons.org/licenses/by-nc/4.0/.

Email Alerting Receive free email alerts when new articles cite this article - sign up in the box at the top Service right corner of the article or click here.

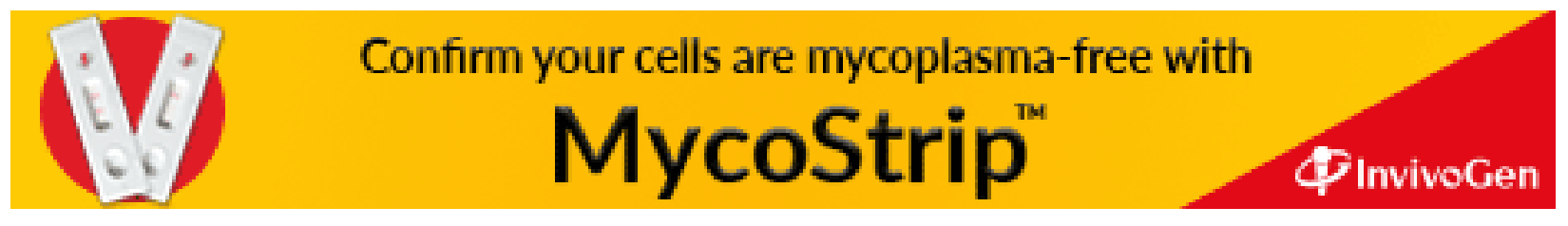

